W Liście Apostolskim Tertio Millennio Adveniente Papież Jan Paweł II pisze, iż wszyscy chrześcijanie powinni „z odnowionym zapałem pow rócić do Biblii”. Towarzystwo Biblijne w Polsce czerpie $\mathrm{z}$ tych słów nowe natchnienie do swojej ekumenicznej służby organizując - już po raz trzeci z kolei ogólnopolskie Ekumeniczne Święto Biblii, Ekumeniczne Soboty, Niedziele i Dni Biblijne. Zachęcamy dziś wszystkich chrześcijan do przylgnięcia do Biblii, do wytrwalej lektury Pisma Swiętego, do osobistych i wspólnotowych spotkań ze Słowem Bożym, do codziennego odkrywania Biblii jako czystego źródła życia duchowego (Por. KO 25).

Tym, którzy Biblię mają, lecz Jej nie czytają przypominamy słowa księcia egzegetów św. Hieronima: ${ }_{n}$ nieznajomość Pisma św. jest nieznajomością Chrystusa". Zapatrzonym tylko w mądrość tego świata przypominamy zdanie polskiego Horacego - Macieja Kazimierza Sarbiewskiego, iż Biblia jest ważniejsza, mądrzejsza i wspanialsza niż „tysiąc Iliad czy Eneid".

Dzień, w którym nie bierzemy do ręki Biblii - to dzień stracony, każdego dnia podążajmy wytrwale na spotkanie $\mathrm{z}$ naszym Bogiem i Panem, obecnym w swoim wiecznie trwałym Słowie.

W tegoroczne Ekumeniczne Swięto Biblii, u progu Ekumenicznych Dni Biblijnych prosimy pokornie wszystkich Czytelników i Słuchaczy niniejszego "Slowa”, by w te dni majowe nie tylko "z odnowionym zapałem powrócili do Biblii", ale by w Niej rozpoznali jedyną Księgę Życia i Mądrości.

Bracia i Siostry! W te Dni na targowisku swiata raz jeszcze rozpoznajmy Biblijne Słowo Prawdy i nie pozwólmy żadnemu Słowu Pana upaść na ziemię. Niech ono będzie naszym światłem, mocą, wytrwaniem i zwycięstwem.

TOWARZYSTWO BIBLIJNE W POLSCE

SPRAWOZDANIA I WIADOMOŚCI

Ks. Jerzy Chmiel

\title{
50. ZJAZD STUDIORUM NOVI TESTAMENTI SOCIETATIS (Praga 1995)
}

W dniach 31 lipca-4 sierpnia 1995 r. w Pradze miał miejsce jubileuszowy zjazd Studiorum Novi Testamenti Societatis (SNTS). Właściwie jubileusz był większy, pierwsza bowiem myśl założenia takiego międzynarodowego towarzystwa skupiającego badaczy NT, pod nazwą „New Testa- 
ment Society”, powstała już w 1937 r. w łonie organizacji „Faith and Order", a spotkanie organizacyjne odbyło się u zarania II wojny światowej we wrześniu 1939 r. Dopiero jednak po wojnie wznowiono działalność: I zjazd miał miejsce w Oksfordzie w 1947 r. Odtąd towarzystwo zaczęło występować pod obecną nazwą: Studiorum Novi Testamenti Societas.

$\mathrm{Z}$ początku protestancka, a obecnie międzykonfesyjna, SNTS spotkała się $\mathbf{w}$ jubileuszowej atmosferze w Pradze, gdzie na Uniwersytecie Karola (założonym w $1348 \mathrm{r}$.) istnieją trzy wydziały teologiczne: protestancki, katolicki i husycki. Można zatem mówić - po 50 latach praktyki - o atmosferze prawdziwie ekumenicznej, co rzeczywiście ma pokrycie w faktach.

Wykład inauguracyjny wygłosił w pięknej auli Carolinum o. A. Vanhoye SI, przewodniczący SNTS na okres 1995-96, pt. „Teleiosis Chrystusa glówny punkt kapłańskiej chrystologii $\mathrm{Hbr}^{\prime}$.

Referaty na sesjach (pół)plenarnych wygłosili (podaję w porządku chronologicznym):

K.-G. Sandelin (Abo-Turku, Finlandia): „Jezus - tradycja a balwochwalstwo".

H. Klein (Sibiu, Rumunia): „Zapowiedź sądu o wymóg miłości. Lk 6,24-26.27 w orędziu wczesnego "hrześcijaństwa".

H.C. Kee (Filadelfia): „Syn Człowieczy: zarłok i pijak. Analiza Q 7:1835 ” (=Łk 7,18-35).

I.H. Marshall (Aberdeen): „Zbawienie, laska i uczynki w późniejszych pismach Corpus Paulinum".

J. Zumstein (Zurych): „Proces relektury w literaturze Janowej”.

M. Dumais (Ottawa): „Zbawienia poza wiarą w Jezusa Chrystusa? Uwagi na temat trzech fragmentów Dz." 25 ".

B.M.F. Van Iersel (Nijmegen); „Słońce, księżyc i gwiazdy w Mk 13,24-

M.J.J. Menken (Utrecht): „Początki Starego Testamentu, Cytat w J 7, 38".

M. Bachmann (Niemcy): „Druga Niewiasta. Synchroniczne i diachroniczne uwagi do Ga 4,21-5,21".

M. Franzmann (Armidale, Australia): „Powtórne narodzenie jako Chrystus a rytuały wtajemniczenia weselnej komnaty w Ewangelii Filipa”.

S.E. Porter (Sheffield): „Studia nowotestamentalne i analiza dyskursu, Przegląd ostatnich badań".

U. Schnelle (Halle - Wittemberga): „Oczyszczenie świątyni i chrystologia Ewangelii Janowej".

Ważna rolę spełniają podczas każdego zjazdu SNTS liczne grupy seminaryjne. Podczas zjazdu praskiego było ich 18 (w nawiasie nazwiska kierowników):

1. Wczesne pisma żydowskie a Nowy Testament (P. van der Horst i J.W. van Henten).

2. Zwoje znad Morza Martwego a początki chrześcijaństwa (J.H. Charlesworth i H. Lichtenberger).

3. Archeologia Nowego Testamentu (R.A. Batey i R. Oster).

i H.C. Kee).

4. Grecko-rzymski kontekst początków chrześcijańatwa (D.L. Balch

5. Jezus historyczny (H.-D. Betz i W. Horbury).

6. Problem synoptyczny (D.Z. Dungan i A. Fuchs).

7. Ewangelia Mateusza (R. Feldmeier i D.A. Hagner)

8. Ewangelia Marka (C. Breytenbach i A. Yarbro Collins).

9. Łukasz - Dzieje: opowiadanie i nowe stworzenie (D. Marguerat i D. Moessner). 
10. Pisma Janowe (R.A. Culpepper i M.J.J. Menken).

11. Paweł i diaspora żydowska (J.M.G. Barclay i F. Siegert).

12. Korespondencja do Tesaloniczan (J. Beutler i K.P. Donfried).

13. Apokaliptyka w Nowym Testamencie (C.H. Giblin i J.-W. Taeger).

14. Wspólnoty chrześcijańskie i judaizm (G. Rochais i M. Quesnel).

15. Krytyka tekstualna (D.C. Parker).

16. Etyka Nowego Testamentu (R.B. Hays i W. Schrage).

17. Hermeneutyka i tekst biblijny (J.W. Voelz i B.C. Lategan). korný).

18. Treść i problemy nowotestamentalnej teologii $(\mathrm{H}$. Hübner i P. Po-

Ekumeniczne modlitwy poranne były prowadzone kolejno przez husytę (Z. Sázava), katolika (J. Swetnam SI) i protestanta reformowanego (M. Carrez).

Miłe wrażenie na członkach zjazdu pozostawiło zwiedzanie Galerii Narodowej na zamku w Hradczanach, koncert w Muzeum Narodowym, na którym wystąpił z recitalem znany czeski pianista $R$. Kvapil, i oficjalne przyjęcie wydane przez Uniwersytet Karola w pięknym, stylowym pałacyku na Wyspie Zofin. Od strony organizacji zjazdu czuwal z dobraną ekipą P. Pokorný, z wydziału teologii protestanckiej, kończący kadencję przewodniczącego SNTS 1994.

Dokonano wyboru przewodniczących SNTS na następne lata i miejsc przyszłych zjazdów. Na rok 1996 przewodniczącym został wybrany G.N. Stanton (Londyn), a na rok 1997 U. Luz (Berno). Zjazd w 1996 r. odbędzie się w Strasburgu (6-9 sierpnia), w 1997 r. w Birmingham (4-8 sierpnia), a na 1998 przewidziano Kopenhagę.

W jubileuszowym zjeździe praskim wzięło udział ok. 300 członków i zaproszonych gości. Z Polski byli obecni członkowie: ks. prof. S. Pisarek (PAT) oraz niżej podpisany,

Kraków

Ks. JERZY CHMIEL

\author{
Ks. Jerzy Chmiel
}

\title{
NAUKI BIBLIJNE A WSPÓடCZESNA SOCJOLOGIA. MIĘDZYNARODOWE SEMINARIUM INTERDYSCYPLINARNE (EMMETTEN 1995)
}

W uroczej miejscowości Szwajcarii centralnej, Emmetten (800 m npm.), położonej nad Jeziorem Czterech Kantonów, Szwajcarskie Towarzystwo Teologiczne urządziło w dniach 14.-17. września 1995 r. międzynarodowe seminarium interdyscyplinarne „Teologia chrześcijańska a współczesna socjologia". 